\title{
Introduction to China's Green Finance System
}

\author{
Huan Peng*, Xiaoqing Lu, Chaobo Zhou \\ School of Economics and Finance, Chongqing University of Technology, Chongqing, China \\ Email: *penghuan@cqut.edu.cn, luoxiaoqing@cqut.edu.cn, zhouchaobo@cqut.edu.cn
}

How to cite this paper: Peng, H., Lu, X.Q. and Zhou, C.B. (2018) Introduction to China's Green Finance System. Journal of Service Science and Management, 11, 94-100. https://doi.org/10.4236/jssm.2018.111009

Received: January 26, 2018

Accepted: February 24, 2018

Published: February 27, 2018

Copyright (c) 2018 by authors and Scientific Research Publishing Inc. This work is licensed under the Creative Commons Attribution International License (CC BY 4.0).

http://creativecommons.org/licenses/by/4.0/

\begin{abstract}
In China, green finance has become a bright spot in the development of the financial industry. The pace of building a green financial system is accelerating. Relevant systems are gradually being established and perfected. China's green finance business has achieved initial development in the past decade. Some policies such as green credit, green insurance and green securities have been issued one after another. This paper analyzes the current situation of China's green financial system, the problems encountered in developing green finance and how to develop green finance better.
\end{abstract}

\section{Keywords}

Green Finance, Environment, Development

\section{Introduction}

In September 2015, in the Integrated Reform Plan for Promoting Ecological Progress issued by the Communist Party of China (CPC) Central Committee and the State Council, China identified the top-level design for establishing China's green finance system [1]. In December 2015, the G20 Green Finance Study Group was established and started to study how to promote the development of global green finance to mobilize more financial resources and speed up the green transformation of the global economy driven by China's initiative. In March 2016, the Thirteenth Five-Year Plan for Economic and Social Development of the People's Republic of China passed by the National People's Congress clearly proposed establishing a green financial system, developing green credit, green bonds and establishing a green development fund [2]. Building a green financial system has risen to be China's national strategy. In August 2016, with the approval of the State Council, seven ministries and commissions such as the People's Bank of China and the Ministry of Finance jointly released the Guidance on the Construction of a Green Financial System, covering 35 articles in 
nine aspects. This document reflects a series of important innovations and outlines the basic framework for the future of China's green finance system [3].

\section{The Definition of Official Green Finance and Green Investment}

Judging from the current situation, China needs to invest 3 trillion yuan to 4 trillion yuan of green investment annually to achieve its goal of environmental pollution control and its international commitment to reach its carbon emissions goal by 2030 [4]. However, the industry estimates that the fiscal fund can cover only about $15 \%$ of green investment, so the vast majority of green investment needs to come from social funds. In other words, China needs to establish a systematic and effective green financial system to mobilize several times or even tens of times its social capital into green industries through limited financial resources. And social capital often fears whether the government has a clear strategic goal and a supportive policy orientation in green investment. Giving the uncertainty of goals and policies, social capital tends to give high discount rates to future projects, and risk premiums that banks and other investors often demand for high investment returns. Therefore, it will lead to the problems of expensive financing and difficult financing [5].

The promulgation of the Guidance on the Construction of a Green Financial System by the seven ministries and commissions approved by the Central Committee of the Committee of the State Council and approved by the State Council shows that China has reached a high level of consensus to fully support and promote China's green investment and financing to speed up the transition to a green economy from the highest strategic level to the relevant ministries and commissions. It will be an important and positive policy signal to guide the financial industry and green enterprises in green investment and financing [6]. It will help reduce investors' worries about the policy uncertainty and encourage more people who know little about green investment to join the green investment.

Green finance refers to the economic activities that support the improvement of the environment, which can cope with climate change and efficiently use resources. In other words, it is the investment, financing, project operation and risk management of projects directed at environmental protection, energy saving, clean energy, green transportation and green building financial services. The official definition of green finance given this time contributes to the definition of green financial products and provides a basis for stimulating green investment through reputation effects. This is also the most authoritative definition of green finance in China so far. This definition includes three meanings. Firstly, the purpose of green finance is to support environmentally beneficial projects while environmental benefits include supporting environmental improvements, coping with climate change and efficient use of resources. Secondly, the major categories of green projects are given, the definition and classification of various green financial products such as green credit, green bonds, green stock will be of 
great guiding significance in the future. Thirdly, it is clear that green finance includes financial services that support investment and financing of green projects, project operations and risk management, which indicate that green finance includes not only financing activities such as loans and securities issuance, but also risk management activities such as green insurance as well as a carbon finance business with multiple functions. Clearly defining green finance and labeling green financial products on this basis will help green enterprises and green investors get the reputation effect they deserve and encourage more green investment [7].

\section{The Development of Green Finance}

\subsection{The Development of Green Bond}

On December 22, 2015, the People's Bank of China (PBC) released the Public Notice of the People's Bank of China (2015) Thirty-Ninth, introducing green financial bonds in the inter-bank bond market, which created a financing channel for financial institutions to raise funds to support green industry projects through the bond market [8]. On the same day, the Green Finance Committee of the Chinese Finance Society released the Green Bond Support Project Catalogue (2015 Edition), which aims to provide issuers with green project definition standards [9]. Since 2016, the circulation of China's green bonds has been the highest in the world. The development of a green bond market has brought many benefits to China like opening up new financing channels for green businesses and projects, resolving the mismatch between banks and businesses, providing investors with new asset classes and strengthening the issuer's green investment through reputation effects behavior as the next step to improve the development of the green bond market. China should establish and improve the domestic definition of green bonds, explore the third party assessment of green bonds and rating standards [10].

\subsection{The Development of Carbon Finance}

The lack of analytical capabilities for their own markets and credit risks associated with polluting investments of some financial institutions may lead to over-investment in polluting industries. The Guidance on the Construction of a Green Financial System firstly put forward a stress test on environmental risk. With a more strict enforcement of the environment law, the enterprises must pay for their pollutant emissions, pushing up cost of production enterprises. The national carbon trading market will be officially launched in 2017. If emission reduction targets of emission control enterprises are difficult to achieve, they must go to the market to buy carbon credits and incur more expenses. Therefore, many polluting enterprises will face rising costs and diminishing returns. For banks, the non-performing loan ratio of these enterprises will also rise accordingly. If stress tests can be used to estimate the future Non-Performing Loan (NPL) ratio of these high-risk industries, the quantitative relationship between 
environmental risk and future credit risk can be obtained, banks can reexamine their own asset allocation and encourage them to reduce their pollution industry loans, while increasing investment in green industry funds [11].

In 2015, China promised to the world its goal of reaching a peak of carbon dioxide emissions by 2030 and announced that it will start running a nationwide carbon trading market by 2017. This is a very important driving force for promoting the transformation of our economic structure to a low-carbon and green one. Developing carbon trading and carbon finance products will also be an important part of China's green finance system. Carbon trading is the institutional arrangements of government creation and market operation, which is also an important tool to solve greenhouse gas emissions and other environmentally-negative external problems. From 2005 to 2013, total carbon emission reductions in the European Union (EU) covered by the carbon trading system reached $13 \%$. Carbon trading and the carbon finance market that builds on it can play many roles such as curbing total emissions, financing financiers and providing risk management tools for carbon market participants. The Guidance on the Construction of a Green Financial System points out that it is necessary to promote the establishment of a unified national carbon market and orderly develop carbon finance products such as carbon forward, carbon swap, carbon option, carbon lease, carbon asset bonds, carbon fund and study carbon emission trading futures. This will encourage the participation of banks, securities, insurance, funds and other financial institutions and promote the formation of institutional arrangements for large-scale financial transactions [12].

\subsection{The Development of Green Insurance}

China's green insurance mainly refers to environmental pollution liability insurance. Environmental liability insurance refers to the insurance business that takes the responsibility of compensation for the damage caused by a third party as a result of a pollution accident. Environmental Protection Law of People's Republic of China amended in April 2014 explicitly proposed to encourage and insure the liability insurance of environmental pollution [13]. In September 2015, the CPC Central Committee and the State Council printed the Integrated Reform Plan for Promoting Ecological Progress and proposed setting up a compulsory liability insurance system for environmental pollution in areas with high environmental risks. At present, more pilot projects on environmental liability insurance should be conducted to create conditions for promoting environmental liability insurance across the country. Later, China will also amend the laws and administrative regulations on compulsory insurance of environmental pollution according to the procedure [14].

\section{Related Measures for Developing Green Finance}

\subsection{Establishing a National Green Development Fund}

China's green finance is mainly confined to green credit. However, many green 
projects, especially new green projects, firstly need equity financing. Some green equity funds should be set up to promote equity financing of green projects. Investment in green industry through a national green development fund reflects the state's guidance and policy signals on green investment. Internationally, the establishment of a green development fund at the national level to demonstrate the central government's strong commitment to green development like China is a rare example.

In fact, many green projects are relatively new. Technically speaking, people feel that the risks are relatively large, and they are also facing policy uncertainties. Due to these uncertainties, private funds are less willing to invest in these green projects. The participation of government funds in these investment projects can greatly reduce the public's risk aversion for such projects, making non-government funds willing to invest. There are many ways for the government to promote the formation of green industry funds such as General Partner (GP) and Limited Partner (LP), while some can become regional green funds and some can become green funds for industries [15]. In the future, China will establish various green developments fund to support the improvement of the environment and the development of green industries [16].

\subsection{Establishing a Clear Incentive Mechanism}

China proposed encouraging the development of green finance through such measures as discount interest, guarantee, re-loan, macro-prudential assessment, simplified examination and approval, and Public-Private Partnership (PPP). Many of these elements work as incentives for green finance.

For example, re-lending, specialized guarantee mechanism and financial interest subsidy can be used to support green-project related credit funding. The macro-prudential assessment framework can study the incentive mechanism for banks with good performance in terms of green credit granting. Local governments should be supported to reduce the financing costs of green bonds through specialized guarantees and credit enhancement mechanisms and other measures.

\subsection{Enriching the Content of International Cooperation in the Field of Green Finance}

At the end of 2015, the G20 included green finance in its 2016 financial agenda and formally approved China's proposal of a G20 green finance research group at the G20 finance and central bank deputy meeting held in Sanya. To further promote international cooperation in the field of green finance, China will continue to promote a global consensus on green finance development under the G20 framework and promote voluntary principles related to green credit and green investment [17]. China should continue to support domestic financial institutions and enterprises to issue green bonds abroad and guide the international funds investing in China's green bonds, green stocks and other green financial assets, encouraging the establishment of a joint-venture green develop- 
ment fund, supporting international financial organizations and multinational corporations to issue green bonds in China, promoting green investment and promoting China's participation in foreign investment projects to strengthen environmental risk management, raise the level of environmental information disclosure, and use green financing tools such as green bonds [18].

\section{Conclusion}

In summary, we can see that green finance has emerged with the development of China, which represents the new direction and trend of the development of the international financial industry and indicates a tremendous change for our country's financial industry. As far as the present situation is concerned, China can improve the financing and Return of Investment (ROI) of green projects by stepping up green finance policies, improving green finance laws and regulations, smoothing information exchange channels, speeding up the reform of financial institutions and strengthening international exchanges and cooperation to build a green financial system that lowers the financing availability and reduces the return of investment for polluting projects.

\section{References}

[1] Communist Party of China (CPC) (2015) Integrated Reform Plan for Promoting Ecological Progress. Central Committee and the State Council.

[2] China Development and Reform Commission (2016) Thirteenth Five-Year Plan for Economic and Social Development of the People's Republic of China.

[3] People's Bank of China, Ministry of Finance and Other Seven Ministries (2016) Guidance on the Construction of a Green Financial System.

[4] National Bureau of Statistics of China (2015) China Statistical Yearbook.

[5] Otani, I., Fukumoto, T. and Tsuyuguchi, Y. (2011) China's Capital Controls and Interest Rate Parity: Experience during 1999-2010 and Future Agenda for Reforms. Bank of Japan Working Paper.

[6] Xing, X.U. and Chen, X.C. (2017) Strategic Conception and Systemic Design of China's Ecological Civilization Construction since the 18th CPC National Congress. Journal of Xuzhou Institute of Technology, No. 4, 12-18.

[7] Shambaugh, D. (2007) China's Propaganda System: Institutions, Processes and Efficacy. China Journal, No. 57, 25-58. https://doi.org/10.1086/tcj.57.20066240

[8] The People's Bank of China (2015) Public Notice of the People's Bank of China Thirty-Ninth.

[9] China Financial Institute Green Financial Specialized Committee (2015) Green Bond Support Project Catalogue.

[10] Qin, X.H. (2015) The Main Approach of Green Bonds Development Promotion in Developed Countries and Enlightenment to China. Financial Theory \& Practice, No. $12,98-100$.

[11] Woo, W.T. (2011) China's Economic Growth Engine: The Likely Types of Hardware Failure, Software Failure and Power Supply Failure. BOFIT Discussion Papers.

[12] Delang, C.O. and Wang, W. (2013) Chinese Forest Policies in the Age of Decentralization (1978-1997). International Forestry Review, 14, 13-26. 
https://doi.org/10.1505/146554812799973145

[13] Standing Committee of Twelfth National People's Congress of the People's Republic of China (2015) Environmental Protection Law of People's Republic of China.

[14] Harter, J.H. (2004) Environmental Justice for Whom? Class, New Social Movements, and the Environment: A Case Study of Greenpeace Canada, 1971-2000. Labour, 54, 83-119. https://doi.org/10.2307/25149506

[15] Brink, T.T. (2012) Perspectives on the Development of the Private Business Sector in China. China: An International Journal, 10, 1-19.

[16] Lan, X. and Li, B.G. (2014) The Economics of Nationalism. American Economic Journal-Economic Policy, 19, 1413-1421.

[17] Reich, A. (2009) The New Text of the Agreement on Government Procurement: An Analysis and Assessment. Journal of International Economic Law, 12, 989-1022. https://doi.org/10.1093/jiel/jgp037

[18] Liao, F. (2011) Regulation of Financial Conglomerates in China: From de facto, to de jure. European Business Organization Law Review, 12, 267-313. https://doi.org/10.1017/S1566752911200041 